\title{
EDITORIAL
}

\section{A New Crisis Manager at the Horizon - The Case of the European Union}

Keywords: European Union; common foreign and security policy; crisis management.

\begin{abstract}
The 1999 Kosovo crisis has forced the European Union to finally give concrete form to its ambitions in the sphere of the common foreign and security policy. At a time when agreement on defence issues seems out of reach, the member states' focus is on the development of a crisis management capability. It is argued that when the Union's diplomatic structures are complemented with military and civilian crisis response tools, much needed balance will be given to the Union's persona as an economic giant and a political dwarf. The article includes a number of measures which should be taken with a view to reinforcing and extending the Union's external role in this field.
\end{abstract}

\section{INTRODUCTION}

Enthusiasts for an ever-closer European Union are chuffed these days. The great venture that started 50 years ago with Robert Schuman's plan for France and Germany to combine their coal and steel industries has developed into something only visionaries then believed in. Common market and single currency are both in place. Yet, the European Union's political and economic order is by no means settled. It is changing rapidly. With clear goals aimed at achieving and maintaining peace, security and prosperity in the region, the time has now finally come to form a political union as well, starting with a common foreign and security policy (CFSP).

The need for action in this field was (once again) illustrated by the military operation of ten NATO countries against the Federal Republic of Yugoslavia (FRY) concerning the humanitarian crisis in Kosovo in 1999. Even though the US was crucial in winning the war against the FRY, its reluctance to get involved - e.g. with ground troops who might have been killed - was more tangible than ever before. Never has it been clearer that the European Union must do more on its own, particularly in its own 'backyard'. In both peacekeeping and reconstruction in the Balkans, it is starting to do just that. ${ }^{1}$ That is new, and welcome.

1. Eurocorps taking on KFOR command in Pristina for six months, Agence Europe, No. 7701 of 19 April 2000. Principles and Guidelines of the EU's Policy towards the Western Balkans, Agence Europe, No. 2150 of 28 July 1999; No. 2156 of 24 September 1999; No. 2180 of 25 March 2000.

13 Leiden Journal of International Law 255-263 (2000)

(c) 2000 Kluwer Law International 
But the European Union's political leaders seem ready for more. By way of their foreign-policy spokesman:

We should be uncompromising in upholding international law and conventions, especially humanitarian conventions. ${ }^{2}$

There seems to be little doubt about the willingness of the member states to use peaceful means to convince third states to abide to international humanitarian and human rights law. Through negotiation, mediation, conciliation, and adjudication efforts, through the implementation of economic sanctions and by adopting and following 'guidelines' on the recognition of new states in e.g. Eastern Europe and in the Soviet Union, the EU is already presenting itself on the international political plane as a guardian of international treaties and a promoter of restoring and maintaining international peace and security. In the context of the aftermath of the war against the FRY, however, the above statement clearly implies the desire of the EU to seek recourse to heavier means to address violations of international humanitarian and/or human rights law. The problem is that the Union's language and its current powers under the CFSP do not "match up" so congruently.

\section{SHAPING THE UNION}

The problems facing the CFSP are part of a wider international challenge with which all security-oriented organizations are confronted. This challenge to global security is reflected in the fact that in 1991, with the exception of the Gulf War, all major conflicts took place within states rather than between states. ${ }^{3} \mathrm{Al}-$ most ten years later, this situation is still the same. ${ }^{4}$ In designing responses to intra-state conflicts a delicate balance must be struck between the main principles which give the international system structure - state-sovereignty, territorial integrity, non-use of force - and the moral and legal obligation to observe and uphold human rights and fundamental freedoms.

Since its renaissance ten years ago, the UN Security Council has authorized the use of military force in a considerable number of cases, usually on the basis of Chapter VII. Only rarely have armed interventions been justified on the basis of Chapter VIII of the Charter. Some of the latter kind of incidents indicate that regional organizations can perform a significant role in conducting armed inter-

2. J. Solana, High Representative of the CFSP of the EU, in his acceptance speech on 10 October 1999, available at http://ue.eu.int/pesc/default.asp?lang=en.

3. SIPRI, SIPRI Yearbook 1992: Armaments, Disarmament and International Security 417 (1993).

4. The exceptions being the disputes between India and Pakistan, and Eritrea and Ethiopia. What started as an intra-state conflict in the Congo has in the past two years drawn in several African states, and has sparked off inter-state clashes between e.g. Rwanda and Uganda. 
vention to enforce compliance with human rights. In general, however, the role of regional arrangements and agencies in the maintenance of international peace and security has, for the most part, been under-utilized. Greater use by the Security Council of these regional organizations to enforce third party compliance with humanitarian and human rights law could yield significant benefits which cannot be achieved through the use of the United Nations alone. Scenarios in which the European Union would take on the role as regional, let alone universal, trouble-shooter seem premature, but not inconceivable in the not too distant future.

Building the European Union is a work in progress. The direction, speed and geometry of the EU are constantly debated. The most recent of debating rounds started on 14 February and will end in December 2000 at Nice with, hopefully, the adoption of a new Treaty on European Union (TEU). While the ongoing Intergovernmental Conference (IGC) is mainly concerned with preparing the institutions and procedures of the Union for a large increase in membership, the main item of "other business" that has also found its way on to the agenda goes by the name of flexibility. This concept reflects the idea of making it easier for any majority group of EU member states, and thus not necessarily all of them, to set up a new institution or a new agreement and to integrate it into EU law. European Monetary Union is an early example. With the lessons from Kosovo fresh in mind, military union could be the next.

Building on the 1992 Maastricht Treaty, the entry into force of the Amsterdam Treaty on 1 May 1999 provided the new basis for further enhancement of the European Union's CFSP. In spite of the emphasis upon the security of the Union (as opposed to its member states), the tools essential for accomplishing this objective are purely intergovernmental. ${ }^{5}$ In addition to modest decisionmaking modifications, the Amsterdam Treaty saw the introduction of a number of new institutional structures intended to help the EU in facing future crises.

\section{THE FACE OF THE UNION: THE HIGH REPRESENTATIVE FOR THE CFSP}

The CFSP has gained visibility through the appointment of Javier Solana as the first High Representative for the common foreign and security policy (and Secretary-General of the Council). ${ }^{6}$ His task is to provide an essential contribution to the enforcement of the CFSP, including a European security and defence policy. According to Article 26 TEU, the High Representative assists the Presi-

5. For a critical analysis of the progress made at the pre-Amsterdam IGC in modifying the decisionmaking procedures of the EU in the field of CFSP, and of the innovation of the common strategies' tool, see S. Duke, From Amsterdam to Kosovo: Lessons for a Future CFSP, 2 Eipascope 2-15 (1999).

6. Art. 18, para. 3 TEU. Since he succeeded Jose Cutileiro on 25 November 1999, Solana also holds the position of Secretary-General of the WEU. 
dency, "in particular through contributing to the formulation, preparation and implementation of policy decisions, and, when appropriate and acting on behalf of the Council at the request of the Presidency, through conducting political dialogue with third parties." His assistance should streamline negotiations on CFSP and should enhance the continuity and consistency of policy-making in this field on the basis of the common interests of the 15 member states. Although the Presidency represents the Union in matters concerning the CFSP, and although the Presidency is responsible for the implementation of decisions taken under the CFSP, ${ }^{7}$ practice from his first nine months in office shows that, so far, Solana has managed to fully exploit the wording of Article 26 TEU. Solana's personal capacity seems to transcend his mere ability to assist the Presidency.

In light of the Kosovo crisis, there are two arguments pleading in favour of the proposition that the High Representative should assume a broad role with appropriate powers of initiative. First, the Troika mechanism does not overcome the Presidency's inevitable problem of inconsistency due to its rotation every six months. The High Representative, appointed for a (renewable?) five-year term, would allow third parties to identify with the CFSP actors for a period longer than six months. Second, the current system of foreign and security policymaking at monthly meetings inevitably results in a reactive agenda. The continuous presence of a High Representative, backed by a permanent body responsible for policy planning and early warning, could lead to a more proactive CFSP. ${ }^{8}$

Calls for more long-term strategies were answered by the 1996 IGC with the adoption of a declaration attached to the Treaty of Amsterdam. ${ }^{9}$ The declaration provides for a Policy Planning and Early Warning Unit (PPEWU), which should monitor and analyze developments in areas relevant to the CFSP; provide assessment of the Union's CFSP interests and identify areas where the CFSP should focus in the future; provide timely assessments and early warning of events or situations which may have significant repercussions for the Union's CFSP, including potential political crises; and produce, at the request of either the Council or the Presidency or on its own initiative, policy papers which may contain analyses, recommendations and strategies as a contribution to policymaking in the Council. Although the respective powers of the High Representative, the PPEWU, the Council and the Presidency are all defined in the Amsterdam Treaty, the relations between the constituents remain unclear.

History has shown that rogue leaders with bad intentions only understand the language of diplomacy backed by force. In Amsterdam, the member states of the

7. Art. 18, paras. 1 and 2 TEU respectively.

8. Duke, supra note 7, at 7-8.

9. Treaty of Amsterdam, Declarations adopted by the Conference, Declaration on the Establishment of a Policy Planning and Early Warning Unit, in OJ C 340/132 of 10 November 1997. 
EU have endowed their CFSP with diplomatic structures which represent only slight modifications to the 1992 Maastricht Treaty. The effectiveness of these modifications depends for a great deal upon the willingness of the member states to use the new structures. It is doubtful whether these structures will significantly alter the ability of the CFSP to address complex intra-state conflicts. The $\mathrm{EU}$ is in need of other, more persuasive machinery to force parties, fighting each other in an armed conflict just outside its borders, to refrain from committing heinous crimes such as ethnic cleansing, religious persecution, and racial discrimination. This need has become apparent, first during the crisis in Bosnia, next in Albania, and then in Kosovo.

\section{WHAT'S NEXT: A MILITARY UNION?}

First steps to establish a military union, since the failure to create a European Defence Community in the 1950s, were taken in Amsterdam with the incorporation of the Western European Union (WEU) into the structures of the second EU-pillar. According to Article 17, paragraph 1 TEU, the WEU is an "integral part of the development of the Union providing the Union with access to an operational capability notably in the context of paragraph 2." Paragraph 2 refers to "humanitarian and rescue tasks, peacekeeping tasks and tasks of combat forces in crisis management, including peacemaking" - the so-called Petersberg Tasks, after the 1992 WEU Council meeting. Ambiguity exists about the question whether future dealings with intra-state conflicts would require EU-led military operations across the full Petersberg spectrum, including peace enforcement. ${ }^{10} \mathrm{It}$ is clear, however, that common defence activities remain outside the Union's realm. Political unwillingness from both NATO members and neutral countries to include a reference to defence matters is reflected in the fact that paragraph 2 remains silent on that point.

The introduction of these paper security structures soon proved inadequate. Faced with reality in Kosovo, where the US and European countries cooperated closely and successfully, both diplomatically and militarily, the EU was simply embarrassed about how little it could contribute to the air campaign against the FRY and about how few troops it could muster quickly enough to police the ceasefire. Even though it is likely to expect that the US, within NATO, will continue to take the lead in dealing with most of the world's trouble spots, the EU should not remain dependent on American cash, guns and troops. In the past, EU interests have diverged from those of the US on a number of issues, ranging from the trade in beef and bananas to the use of armed force in Iraq and Libya. Moreover, reliance upon US diplomacy and NATO's military strength would

10. For further details, see F. Pagani, A New Gear in the CFSP Machinery: Integration of the Petersberg Tasks in the Treaty on European Union, 9 EJIL 737-750 (1998). 
condemn the Union to crisis management and not shift the emphasis on crisis prevention, for which the EU is better equipped. Crisis prevention would capitalize on the EU's greatest asset, i.e. the promise of association or, for European states, future membership. ${ }^{1}$ In near-at-hand places like the Balkans, the US would probably be more than happy to defer responsibility for regional security to the EU. And in areas like the Middle East, the EU ought to be able to play a complementary role to the US.

Frustration about inadequacies such as the ones mentioned above has led Britain and France, the member states that pack most military punch, to prod their colleagues at the European Council's 1999 Helsinki summit in carrying forward work on the development of the Union's military (and non-military) crisis management capability with the objective of a strengthened and credible common European policy on security and defence. ${ }^{12}$

At its meeting in Helsinki the European Council underlined its determination to develop an autonomous capacity to take decisions and, where NATO as a whole was not engaged, to launch and conduct EU-led military operations in response to international crises. ${ }^{13}$ In furtherance of this objective the European Council agreed that:

by the year 2003 , cooperating together voluntarily, [Member States] will be able to
deploy rapidly and then sustain forces capable of the full range of Petersberg tasks as
set out in the Amsterdam Treaty, including the most demanding, in operations up to
corps level (up to 15 brigades or $50,000-60,000$ persons). These forces should be
militarily self-sustaining with the necessary command, control and intelligence capa-
bilities, logistics, other combat support services and additionally, as appropriate, air
and naval elements. Member States should be able to deploy in full at this level within
60 days, and within this to provide smaller rapid response elements available and de-
ployable at very high readiness. They must be able to sustain such a deployment for at
least one year. This will require an additional pool of deployable units (and supporting
elements) at lower readiness to provide replacements for the initial forces."

This so-called "common European headline goal" represents a political commitment of the member states to progressively improve the Union's military capabilities for crisis management operations. Further elaboration of the headline goal will need to devote particular attention to the WEU and/or NATO assets

11. Duke, supra note 7 , at 10.

12. As a result of a meeting between President Chirac and Prime Minister Blair in St.-Malo, a Joint Franco-British Declaration on European Defence was issued on 4 December 1998; available at http://www.ambafrance.org.uk.

13. Helsinki European Council Summit, Presidency Reports on Strengthening the Common European Policy on Security and Defence and on Non-military Crisis Management of the European Union, annexed to the Presidency Conclusions, 11 December 1999, available at http:/ue.eu.int/en/Info/eurocouncil/index.htm. The reports propose concrete measures and provide guidance for further work to take the necessary decisions by the end of the year 2000 towards the objectives set at the Cologne European Council Summit, 3 and 4 June 1999. 
and capabilities required to ensure effective performance in crisis management. Keywords are deployability, sustainability, interoperability, flexibility, mobility, and command and control. These objectives of capability improvement should be mutually reinforcing.

In furtherance of this headline goal, the European Council agreed on new political and military bodies and structures to be established within the Council to ensure political guidance and strategic direction, ${ }^{14}$ and on the principles for consulting and cooperating with non-European allies and NATO. Measures to enhance the Union's non-military capabilities in the area of crisis management were also agreed upon, ${ }^{15}$ as was a timetable for carrying forward work on all of these issues.

The trouble with the Helsinki headline goal is that it gives insufficient detail for the purposes of military planning, raising questions such as where EU-led task forces might be expected to operate, with whom, and how often. Some of the key figures in the headline goal - e.g. 60 days - are also open to interpretation. Therefore, agreement on a number of issues is needed before progress can be made on the subsequent steps of the process. ${ }^{16}$ The following measures should be taken in support of the CFSP with a view to reinforcing and extending the Union's comprehensive external role by 2003 :

- Geographical area: the EU should plan on the basis that the most demanding missions will occur in and around Europe. Forces should also be available and able to respond to crises world wide, preferably on the basis of a prior mandate of the UN Security Council and in accordance with the principles of the United Nations Charter;

- Contributions: in addition to the commitments by the EU member states, contributions to the overall improvement of European military capabilities should be invited from European NATO members who are not EU member states, as well as candidate states for EU membership;

14. Following up on an agreement reached by the defence ministers of the EU at their informal meeting at Sintra on 28 February 2000, the interim structures preparing the future European Military Committee and European Military Major Staff, started their activities in Brussels on 1 March 2000. These organs, together with the Security and Politics Committee, will allow the EU to adopt the necessary political strategy in order to become conversant with standard operations as 'Petersberg'.

15. A civilian crisis response committee - the establishment of which should be decided upon by the Feira European Council Summit of 19 and 20 June 2000 - could make a valuable contribution to the Union's crisis management capability, because it could, inter alia, help improve the coordination of resources of the $\mathrm{EC}$, the $\mathrm{EU}$ and the member states through the exchange of information; ensure improvements in the crisis response capabilities of the EU, available both for EU operations and those led by other international organisations; identify opportunities for pooling resources; it could help consider the possibilities of developing common methods, procedures and routines; and it could enhance coordination between member states and NGOs.

16. See the Council's preparatory document No. $6765 / 00$ of 14 March 2000 on the elaboration of the Helsinkj headline goal, "Food for Thought", available at http:/ue.eu.int/newsroom/main.cfm? $\mathrm{LANG}=1$. 
- Scale of effort: in order to be able to undertake complex peace enforcement tasks as well as the rest of the full range of Petersberg missions, the EU will require access to a ready pool of various types of military selfsustaining brigades. This pool could be regarded as the source from which an appropriate force package could be constructed, depending on circumstances, of up to $50,000-60,000$ troops;

- Concurrency: the EU should be prepared to maintain one longer term operation at less than the maximum level and at the same time be able to conduct another Petersberg mission of limited duration;

- Endurance: the EU should plan to sustain a deployment of forces, able to undertake the most demanding mission, for a period of at least one year;

- Readiness: the EU should plan for forces to be held "on call", sufficient to deploy in full in or around Europe within 60 days of a Council decision. In addition, the EU should plan to provide a smaller rapid response element of immediate reaction forces at very high readiness;

- Sustainability: the EU should plan to deploy forces with sufficient holdings to conduct Petersberg missions until their re-supply has been established. The EU should then be able to sustain up to 60,000 troops deployed for a period of at least one year.

With the enhancement and combination of military and civilian crisis response tools, the Union should finally be able to resort to a whole range of instruments, from diplomacy, humanitarian assistance, and economic measures to military crisis management operations.

\section{THE TIMES THEY ARE A CHANGING}

It has been recognised that there is a need to restore the equilibrium between the development of the Community as an economic entity and the Union as a political entity, especially because the economic aspects of the Community's activities often cannot be separated from the political or security ramifications. ${ }^{17}$ The goal of European integration will therefore essentially remain incomplete without a security and defence angle.

In view of the Union's incapacity to act in Kosovo, it is tempting to conclude that the fifteen member states will not be able to overcome their contradictory positions on matters which are close to their hearts: foreign policy and security issues. However, like European Monetary Union, the creation of a military union is inevitable. The Helsinki headline goal already represents a political commitment of all member states to progressively improve the Union's military ca-

17. Vienna European Council Summit, Presidency Conclusions, 11 December 1998, available at http:// ue.eu.int/en/Info/eurocouncil/index.htm. 
pabilities for crisis management operations. In the name of flexibility and with a clear mandate, a majority group of EU member states should now be enabled to move ahead in developing an autonomous capacity to launch and conduct EUled military operations in response to both international and internal armed conflicts in and outside Europe. Government representatives - on the fringes of their negotiations in the ongoing IGC - should give a majority of EU member states such a clear mandate, ideally through the introduction of an enabling clause in the framework of Title V (CFSP) of the new Treaty on European Union.

The ongoing IGC could not only satisfy the desire of a majority of member states to finally move beyond the largely paper security structures, it could also realise the member states' ambition to draft a so-called European charter of fundamental rights, by producing, by the end of 2000 , a text suitable for bolting it straight into the new TEU - or for attaching it to the treaty as a protocol or declaration, which would give it less legal weight.

It seems that the Unjon's efforts to suppress even the slightest suspicion of tolerating disrespect of human rights and fundamental freedoms at home, would help the EU in demanding compliance with humanitarian and human rights law abroad. Seen in this light, the reaction of fourteen member states - acting as a group of like-minded governments rather than on behalf of the EU itself (which would have obliged them to include Austria) - to suspend all bilateral political high-level contacts with Austria when the far-right Freedom Party, lead by $\mathrm{Mr}$ Haider, entered government on 4 February 2000, is understandable. Although the fourteen member states did not spell out the reasons for their snub, it was unmistakably intended as a strong message that intolerance and xenophobia are unacceptable in the European Union of 2000. Nor did the Union's leaders appear unaware of the historic moment of their decision, which "represents a symbol and a lesson for the world". ${ }^{18}$

Steven Blockmans

18. Statement of the Portuguese Presidency of the EU on Behalf of XIV Member States, 31 January 2000 , available at $\mathrm{http}: / / \mathrm{www}$. Portugal.ue-2000-pt/news. 